\title{
Advanced Favorable Non-Hodgkin Lymphoma
}

National Cancer Institute

\section{Source}

National Cancer Institute. Advanced Favorable Non-Hodgkin Lymphoma. NCI Thesaurus. Code C53283.

A clinical stage II or IV non-Hodgkin lymphoma with up to three of the following risk factors: albumin level less than $4.0 \mathrm{~g} / \mathrm{dl}$, hemog lobin level of less than $10.5 \mathrm{~g} / \mathrm{dl}$, male sex, forty-five years of age or older, stage IV disease, white cell count of at least 15,000 per cubic millimeter, absolute lymphocytic count of less than 600 per cubic millimeter or a lymphocytic count of less than $8 \%$ of the total white cell count. 